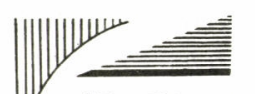

解 説

\title{
プロペラ軸スリーブのグランドパッキン部の 衰耗に対する補修策*
}

\section{1. はしがき}

今日，外部から見れば工業技術の粋を集めたように思 われる造船分野に扔いて, 特に軸采に関し, 構造的にも その信頼性においても極限設計が行なわれているとは考 元難い, 実際には, 構造的にも材料的にも改良開発の余 地がまだまだ残されていると思われる. 軸系の改良は， その損傷が及ぼす船の入きょと工事費あるいは不か動損 失が大きいために，たとえ改良点にすぐれていても実船 に採用され難く,これが悪循環となって, 旧態依然たる 構造からの脱皮が円滑ではない。

たとえば，昭和 39 年 7 月に船尾オイルシール装置が 日本商船に始めて採用されて以来 ${ }^{1)}$ ，その普及は目ざま しくて，今では物めずらしくないと思われ勝であるが， それは大手船主や大手造船所の場合であって, 現在なお, 建造船の半数以上は水潤滑方式を採用している. もっと も, これはオイルシール装置が日本では大形船の方から 普及したことと価格のバランスの問題からの結果論とも いえる.

キーレスプロペラを例にとれば，昭和 46 年 11 月に日 本商船に初めて採用され，それから 7 年目の現在, 約 150隻に達する日本船がこれを使用しており，その技術 的信頼性は十分に立証されたが ${ }^{2)}$ ，旧態依然たるキー付 きプロペラをいまだに愛用している例が多いのは不思議 といえる現状である。なぜなら, 軸系における改良の中 で, キーレスプロペラほど利点が多くて, 且つ, 開発途 上でなんら問題を生じないまま成功のうちに実績を重ね たものはまれだからである.

軸系構造は各造船所とも不偏的であり,なになに式と 称する軸系が普及するには間があると思われるが，それ でもシール装置や船尾管軸受等について, 専門メーカ製 品が使用され始めていることは, 少なくとも昭和 30 年 代とは大きな隔たりがある.

これは, 日本造船研究協会が昭和 41 年から行なった 軸系に関する諸問題の骨子の基礎研究の成果 ${ }^{3), 4), 6)}$ によ るところが多い，しかし，今日なお軸系については究明 すべき課題が残されており, 特に水潤滑船尾管軸受方式 の場合にあっては, 解決策の見いだされないまま昔なが らの悩みを持続している問題がある.

*原稿受付 昭和 53 年 4 月 21 日

** 正会員 (財) 日本海事協会 (東京都港区赤坂 2-17-26)
久米宏 ${ }^{* *}$

琴時点は, 水潤滑船尾管軸受の旧態依然たる構造材料 の軸系の建造船が約半数で, 残る半数について革新が行 なわれつつあるとみなしうる.

さて，この約半数についてみると，現在なお旧態依然 たる問題が残されているわけで, 船の使用者からみると, 昔からなんら改善が加えられていないため, ここ数十年 にわたる問題点が，今日も同じ問題として提起される結 果を招くことは極めて残念なことである. もっとも，船 の使用者の方が保守的とならざるを得ない環境にあるこ とを考虑すれば，いたちごっこと考えることもできる，

この問題点とは, 水潤滑式の場合のグランドパッキン 下のプロペラ軸スリーブの摩耗と電食である.

プロペラ軸スリープの摩耗や電食は, 損傷と呼べるか 否かは別として, 新造時から, かなり年数を経た時点で 必ず生じる船主側の苦痛の一つといえるが, 一般には, その設計者は関与しない問題である. 軸スリーブの換装 は, 入きょ, 船からの軸の搬出搬入工事, そして船の不 か動損失と重なって, 多額の補修費を必要とする. 特に, 最近のように売船が増えると, その時点でスリーブを換 装すべきか否か，換装するとすればその費用を誰が負担 するかが問題となる.

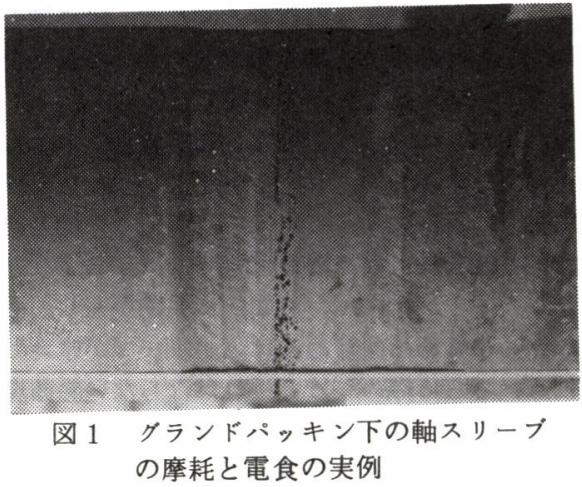

現時点において, この問題の適確な解決策はなにか, そして, 設計時にさかのぼった場合, 当初から設計的対 策を講じることができなかったかなどを考えると, 設計 者は知らないこととはいえない事項である. 特に, 今日 も旧態依然たるグランドパッキン方式を採用した設計の 船が生まれているから, これらの船について, 将来に同 様な問題を生じることは明らかである.

そこで, 本稿は, 水潤滑式船尾管軸受を装備する船舶 
について,グランドパッキン下の軸スリーブの衰耗の補 修対策の現状とその一環としての海水シール装置の機構 の改良についてとりまとめ参考に供するものである.

\section{2. 軸スリーブの挙動と損賃の現状}

軸系がストレートアライメントの場合, プロペラ重量 を主とする曲げモーメントに基づくたわみによって，船 首側船尾管軸受部でおよそ $0.3 \mathrm{~mm}$ 前後ほど軸が浮き上 がる．船尾管軸受のすき間は，およそ $1 \mathrm{~mm}$ はあるから， 軸は，そのすき間内で浮いていることになる. 一方，プ ロペラ軸は, プロペラの生じる変動スラスト（このスラ ストの積分集中点は, 軸中心線から偏心し, この偏心量 も時間的に変動する)に起因する変動曲げモーメントに よって横振動を生じる. この横振動の変位量 (半径方向 の振動振幅) は普通 $\pm 0.3 \mathrm{~mm}$ 程度である. 軸が浮き上 がった状態で, このような大きさの振動をしても, 船首 側船尾管軸受部で, 軸は軸受とほとんど接触しない.す なわち, 船首側の船尾管軸受は, 通常は軸受としての役 目を果たしておらず，船尾管から軸を出し入れするとき の支え台として役立っている. この軸受が軸受として働 くのは, 船尾側の軸受が摩耗したときであるが, 船尾側 と船首側の両軸受の間隔が近過ぎるので, もし, 船尾側 軸受が摩耗すると船首側軸受部での軸の曲げモーメント が増大するので好ましくない. 一般に, 軸受間隔は許さ れる限り長い万がよいので, 最近の船のように, 機関室 を船尾へ追いやり, プロペラ軸が短くなるほど, この船 首側の船尾管軸受の存在は疑問である. もし，この船首 側の船尾管軸受に当初から荷重を分担させ, 軸受として 使用するためには, 最後部中間軸受を下げ, その上メタ ルに反力を持たせるようなスロープフライメントの設計 が必要である. このような設計をすれば, 船首側の船尾 管軸受部で軸が軸受から浮き上がったり, 横振れをさせ ないように拘束することができる.

グランドパッキン部は, 船首側船尾管軸受のすぐ前に あるから,この部分のプロペラ軸も, 上述したと同様な 環境にあり，横振動をしている. このように横方向に振 動している軸を横方向に締めつけてシールしようとする グランドパッキン方式は, 機構的に欠陥があり, 漏水を 止めるために締めれば締めるほどスリーブが摩耗し, 摩 耗すれば,さらに締めつけなければならない悪循環を繰 返すことになる.

さらに, グランドの下の軸スリーブは, グランド材と の距離が極めて近く，ある電位をもち，且つ, 海水中に あるので, 電気化学的腐食を生じやすい. すなわち, こ のグランドパッキン下の軸スリーブは, 摩耗と電食のた めに, 経年的に衰耗して行き, いつの日にか船主にとっ て泣き所となるものである. そして, この補修のために, スリーブを換装することは, 工費及び工期等の面から容 易なことではない. これに対処して, 設計当初から, そ の対策を講じておくことは, 設計者に与えられた課題で
はないであろうか. 一方, 軸スリーブの摩耗および電食 に対して，有効な補修策はないであろうか.

\section{3. 軸スリーブの補修方法の現状}

軸スリーブは焼ばめされているので，この焼ばめ応力 を解放するような熱を加えることはできず，低温補修が 条件となる.

これまでの補修方法の実績例としては，まず「モリブ デンューティング」があげられる. これは, 接着剤(高 分子化学材料) と二硫化モリブデンの混合材を塗布し, 乾燥後に整形するもので, 現場補修が可能である. この 補修方法は安易ではあるが，パッキンの締め付けとの関 連において，はく離することがあり，永久補修策とは必 ずしもなり難い.

次に,「メタライジング」があり，これは銅材の溶射 肉盛り法である.この方法は，低温溶接の一種であるが， 軸スリーブとの溶着というより, 溶射材同志の円筒輪状 の結合による締め付けとみなせるものである. すなわち 溶射後の残留引張り応力に加え, 均一組織の溶射技術の 困難性などから, 補修後, 締め付けによる加熱と海水に よる冷却の繰返しに起因して, 割れやはく離を生じるこ とがあり，これも永久補修策とは必ずしもなり難い. 以 上の二種は，いずれも補修材が自身の輪で軸スリーブを 抱き締める方式といえるものである.

これらのほかに, 最新の補修技術として「ニッケル・ メッキ」がある.これはメッキであるから，補修という よりも完全な原形復㷌といえるもので, 耐摩耗性もよく, 新造当初から，これを盛った例もある. 残念なことに, メッキのために，軸を工場に搬入する必要があり，また メッキに長時間を要するので, 補修用としては難がある が、スリーブを廃却することに比較すれば採算の合う補 修策である.

以上のような補修は摩耗に対する対策であるが，「メ タライジング」や「ニッケル・メッキ」は電食の問題につ いて必ずしも対策とはならない。

一般の青銅スリーブ材は, 相対軸電位が約 $200 \mathrm{mmV}$ 以上あると電食に耐えられず, アース装置を施しても， その接触抵抗のゆえに, これを下回る電位とすることは 困難のようである.「ニッケル・メッキ」を施行した場 合は, およそ $300 \mathrm{mmV}$ の電位に耐えられるので, アー ス装㯰さえ完全であれば，電食に対しても対策となりう るようである注).

以上のように, グランドパッキン下の軸スリーブの摩 耗および電食についての問題は完全に解決されたとはい えず, その優れた補修策の導出はこれからの開発研究課 題と思われる.

注）これらの軸龟位と電食との関連についての試験は,三菱重工業(株) と勝川九州ミカローム工業(株) との共同研究によるもので, 追っ て発表されるとのことである. 


\section{4. 海水シール装置の改良}

軸スリーブの衰耗部を肉盛るのは直接的な補修策であ るが,より優れた間接的な補修策としてグランドパッキ ン方式そのものを廃止することが推奖される.

前述したとおり，横方向に振動する軸を横方向に締め 付けるシール方式は機構的に欠陥があり，横方向の振動 に対して自由な端面シール方式の方が好ましい.

この端面シール装置の国産品としては, 日本ピラー工 業侏の「STB」, イーグル工業侏の「EVK」およびキ ーパー侏の「スターンキーパー」がある.

これらの装置は, 就航船でも, 軸スリーブが衰耗のま まの状態で, 一部整形するだけで取り付けられる. ただ し, 衰耗のまま放置するといっても限度があるので, 検 査に際してスリーブ換装を指定される前の段階で, でき る限り早期に採用するのが好ましい.

これらの装置は機構的に差があるが，いずれも非常用 シールを別に備えている. この非常用シールは空気チュ ーブ式で, 非常時に空気圧でふくらませるもので, その 操作は容易でシール性能も極めて優れており，洋上にお いて，主シール部の補修換装が可能なばかりでなく，場 合によっては, 危急用として短時間は主シールに代えて 使用することができる. さらに, 停泊中にこの非常用シ ールを操作すれば, 船尾管内部からビルジウェルへの漏 水を完全に遮断することができるなど, その価值は非常 に高い.

これらの端面シール装置については, 使用実績も増加 し, 信頼性も向上したので, やがてグランドパッキン方 式に取って代わるものと期待されるが, 現在のところ,

就航船に採用されるのがほとんどである. しかし，本来， これは建造当初から採用する方が好ましいものである.

残念なことに，建造船価の影貔で，これを当初から採用 することをきらう傾向がみられるが, 船の生涯と運航管 理面から考えた場合, 船主にとっても有益なものであり, 一方, 設計者もその採用を当初から推奖すべき性格のも
のと思われる.

この端面シール装置を採用しない場合でも, せめてグ ランドパッキン方式に非常用空気シールを組合わせてお くことが推奖されるが，実例はなく，今後の開発課題の 一つである. 機関室隔壁にある船尾管の穴は, 本来はそ のシール方法が規制されるべき重要な箇所であって, こ のグランドパッキン部からの漏水によって沈没した船の 実例がある.

\section{5. あとがき}

上述したように, 現在もなお新造船の半数は, 旧態依 然たるグランドパッキン方式を採用した構造の水潤滑船 尾管軸受方式であり，最近オイルバス方式が普及したと はいっても, 就航船のほとんどは水潤滑方式である. 漁 船その他の小形船を含めると, 全就航船舶に対してオイ ルバス方式の船の隻数の占める割合は微々たるものであ る. したがって, 設計者は水潤滑方式の設計上の改良点 あるいは損傷の実態と補修策などを十分に認識しておく 必要があるが，久しくオイルバス方式の大形船に追われ ていたので，水潤滑方式をおろそかにしていたといって も過言ではないと思われる.

この造船不況の折から，どのような軸系方式の船でも 設計しなければならない環境に追い込まれるとすれば, 水潤滑方式についての改良の遅れは早急に取りもどさな ければならない課題と考えられる.

\section{文献}

1) 舶機誌 6-2(昭 46-2)，99.

2) 久米; 絈機誌 12-6(昭 52-6), 418.

3) 日本造船研究協会, 研究資料 No.59(昭 42), No.70 (昭 43), No. 90 (昭 44), 以上は第 93 研究部会.

4) 日本造船研究協会, 研究資料 No.116 (昭 45), No.131 (昭 46), No.149 (昭 47), 以上は第 114 研究部会.

5 ) 日本造船研究部会, 研究資料 No.204 (昭 49), 第 143 研究部 会. 